\title{
Adaptív klinikai vizsgálati technikák a gyógyszerfejlesztésben
}

\author{
Antal János dr. \\ PAREXEL Magyarország Kft., Budapest
}

\begin{abstract}
A gyógyszerfejlesztés humán, klinikai vizsgálati módszertanának folyamatos fejlődése igényli azon új módszerek áttekintését, amelyeket összefoglalóan adaptív klinikai vizsgálati technikáknak nevezünk. Ezen metodikákat járja körbe a cikk klinikai, metodológiai oldalról. Orv. Hetil., 2015, 156(48), 1949-1955.
\end{abstract}

Kulcsszavak: klinikai vizsgálat, adaptív, gyógyszerfejlesztés

\section{Adaptive clinical study methodologies in drug development}

\begin{abstract}
The evolution of drug development in human, clinical phase studies triggers the overview of those technologies and procedures which are labelled as adaptive clinical trials. The most relevant procedural and operational aspects will be discussed in this overview from points of view of clinico-methodological aspect.
\end{abstract}

Keywords: clinical study, adaptive, drug development

Antal, J. [Adaptive clinical study methodologies in drug development]. Orv. Hetil., 2015, 156(48), 1949-1955.

(Beérkezett: 2015. szeptember 10; elfogadva: 2015. október 8.)

\section{Rövidítések}

EMA $=$ European Medicines Agency FDA $=$ Food and Drug Administration; $\mathrm{eCRF}=$ electronic Case Report Form; $\mathrm{ePRO}=$ electronic Patient Reported Outcome

\section{Bevezetés rövid orvostörténeti kitérővel}

A humán, klinikai vizsgálatok ma tapasztalható összetettsége, eszköztára csak pillanatnyi állapot egy hosszú fejlődési folyamatban. Az adaptív vizsgálati elemek is már több mint 20 éve megtalálhatók a gyógyszerfejlesztés arzenáljában, viszont azok elterjedtsége csak mostanában érte el azt a szintet, hogy mindenki, aki vizsgálóként, hatósági szakemberként vagy éppen a szponzort képviselve részt vesz a hatóanyagok fejlesztésében, mindenképpen találkozni fog azokkal.

Az első prospektív humán vizsgálatnak is tekinthető történetet 2100-2600 éve jegyezték le, mint arra prof. Káldor Antal (1925-2005) szellemesen felhívta a figyelmet. A Bibliában, Dániel könyvének 1. részében található egy „nyílt, kétkarú, prospektív vizsgálat” leírása.
Dániel nemes, zsidó fiatalemberként, de túszként élt többedmagával a hódító babiloni király, Nabukodonozor (Kr. e. 604-562) udvarában. Nem fogadta el, hogy az udvartartás a zsidó vallás által tiltott ételek és alkohol fogyasztására kényszerítse oót. Ekkor ajánlotta Dániel az udvarmesternek, hogy 10 napig a zsidó vallásúak követhessék saját étkezési szokásukat, és utána egészségi állapotukat hasonlítsák össze azokéval, akik a babiloni király által kötelezővé tett ételeket, italokat fogyasztották. Mint az sejthető, „tíz nap múlva szebbnek látszék az ő ábrázatuk, és testben kövérebbek valának mindazoknál az ifjaknál, akik a király ételével élnek vala". Nagyot ugorva az időben egy másik mérföldkő az első kettős vak, randomizált, placebokontrollos, klinikai farmakológiai vizgálat. Ezt 1944-ben az Egyesült Királyságban, a Medical Research Council égisze alatt végezték. Közel 1500 betegnek adtak vagy patulint, vagy placebót. Tekintettel arra, hogy a Penicillium patulum gomba terméke, a patulin és az abból elóállított spray nem volt jobb a meghúléses panaszok enyhítésében, mint a placebo, ez a metodikailag igen fontos vizsgálat - mint mérföldkő a gyógyszerfejlesztésben - a feledésbe merült. A rövid, 
orvostörténeti kitérő után figyelmünket napjaink gyógyszerfejlesztésének egyik legfontosabb vizsgálati típusára, az adaptív vizsgálati elrendezésekre fordítjuk.

\section{Adaptív klinikai vizsgálat és annak meghatározása}

Mindenekelőtt az adaptív vizsgálati tervezést meg kell különböztetnünk a vizsgálati terv módosításától. A vizsgálatok zömében időről időre protokollmódosítás(oka)t adnak ki, hagyatnak jóvá klinikai, operatív vagy statisztikai okokból. Egy vizsgálatban átlagosan 2-3 protokollmódosításra kerül sor, de nem ritka, hogy 5-10 'protocol amendment'-et is életbe léptetnek. Ezt a kényszerú változtatást reaktív protokollrevíziónak tekinthetjük. Nincs általános elfogadott definíciója az adaptív klinikai vizsgálatoknak. Az FDA- és EMA-meghatározás szerint az adaptív metodikákra jellemző, hogy azok előre megtervezett szóbajövő változtatások, amelyeket a vizsgálat szimulációja és a lehetséges kimeneteleinek vizsgálata alapján állítottak fel. Ezek a változtatások - amelyek az adatok időközbeni analízisén nyugszanak - érinthetik a klinikai vizsgálat egy vagy több, előre meghatározott elemét annak menete során.

$\mathrm{Az}$ adaptív klinikai vizsgálatban, pontosabban annak vizsgálati tervében, elöre modellezik mindazon fontos, döntési helyzeteket, amelyek a klinikai vizsgálat során előreláthatóan előfordul(hat)nak és a vizsgálat menetének módosítását indokolhatják $[1,2]$.

Ezek a változtatások egyrészt magában a futó vizsgálatban addig összegyúlt adatok alapján válhatnak szükségessé, másrészt más kutatásokból érkezhetnek. Ilyen források lehetnek a párhuzamosan futó, humán vizsgálatok, amelyek például a javasolható dózistartomány vagy a várható mellékhatások tekintetében hoznak új információt. Figyelembe vehetnek hasonló, de más hatóanyagokról beérkezett biztonsági, biomarker- stb. ismereteket is. Érdemes tudni, hogy egyes, hosszú, nagy elemszámú állatkísérletek adatai - például onkogén rizikó tekintetében - gyakran csak a fázis 3-as vizsgálat indítása előtt állnak rendelkezésre. Az adaptív vizsgálati protokoll ezen jellegzetességei nem a már futó vizsgálat alatt meghozott ad hoc változtatások, hanem a vizsgálat elindítása előtt meghozott stratégiai döntések, az eredeti protokoll szerves részei $[3,4,5,6]$.

Az eddigi klinikai gyógyszer/hatóanyag vizsgálati tapasztalatok, az online adatgyújtés és -elemzés, a gyors és flexibilis logisztika múködtetése mind hozzájárult az adaptív klinikai vizsgálat eszköztárának kialakításához. A számítástechnika ma már lehetővé teszi, hogy (1) a betegtől a betegnaplót, a kérdőívek bejegyzéseit (ePRO), (2) a vizsgálati centrumból az elektronikus betegadatlapból (eCRF) a klinikai adatokat, (3) a központi laborokból a mérési eredményeket kövessék vagy az egész adatállományt felhasználva az esetleges trendeket elemezzék. A vizsgálat alatt az események folyamatos, egyidejü követése és a változások azonnali visszacsatolása alapján gyorsabban, flexibilisen, sok esetben kevesebb bevont beteggel lehet megválaszolni a hatásossági/hatékonysági, biztonságossági kérdéseket összetett humán vizsgálatokban.

A vizsgálat további menete az előre lefektetett metodikai kereten belül, a változások trendjeinek figyelembevételével megváltoztatható. Ez a keret mutatja meg, hogy meddig nem kell a változtatásokhoz újabb hatósági engedély, etikai jóváhagyás. A protokollban részletezni kell azokat a kontrollmechanizmusokat is, amelyekkel az adaptív változtatások menetét, következményeit ellenőrzik. A protokoll természetesen egy és ugyanaz, hiszen az már a kezdeteknél tartalmazta az időközben bevezetett változtatás lehetőségét és az annak okán szükségessé váló operatív, statisztikai módosításokat.

Az adaptív vizsgálati elrendezéseknek több hasznos hozadéka lehet:

- Hatékonyabban (például kevesebb betegen, rövidebb idő alatt) lehet a szükséges klinikai információt begyújteni.

- Növeli az esélyét, hogy a vizsgálat kimenetele alapján a terápiás beavatkozás hatásosságát, biztonságosságát meg tudjuk itélni.

- Jobban megérthetővé teheti a kezelés hatását (például az alkalmazott dózisok és észlelt változások összefüggése a lényeges dózistartományra fókuszál).

Ugyanakkor fennáll a veszélye, hogy egy bonyolult adaptív vizsgálati elrendezés végeredményéből - éppen a még limitált tapasztalat okán - pontatlan következtetést vonnak le.

\section{Leggyakoribb adaptín vizsgálati technikák}

Az alábbiakban röviden ismertetjük a legfontosabb prospektív, adaptív vizsgálati metodikákat. Ebben az összefoglalóban nagyban támaszkodunk Shein-Chung Chow publikációira $[7,8]$.

1. Adaptív randomizáció során, a vizsgálat alatt a randomizáció menetét előre meghatározott keretek között megváltoztathatják. Ez a változtatás alapulhat az addig észlelt terápiás válaszon, ekkor ezt az eljárást kimenetelfüggő adaptív randomizációnak (response-adaptive randomization) nevezik (1. ábra). Ennek alkalmazását megkönnyíti, ha a klinikai hatás hamar észlelhető, például: intenzív osztályos események kezelése, akut fájdalom szindróma. Felmerül az orvosetikai kérdés: mi van, ha valamelyik vizsgáló bizonyos betegek bevonását csak a köztes adatértékelés utánra tartogatja, mondván, akkor nagyobb eséllyel kerülnek kevezőbb kezelési karba. Ezt valamelyest ki lehet védeni, ha több ilyen időközbeni adatértékelés is történik, és nem tudni, melyiknél változtatnak a randomizáción. Nagyon fontos, hogy az egyes kezelési karokban a randomizációban történő változtatás után is a betegek meghatározó klinikai jellemzői azonosak maradjanak. Amennyiben ezek a betegjellemzők (prognosztikai biomarkerek) befolyással vannak a vizsgált kezelés kimenetelére, és ezek megoszlása nem azo- 


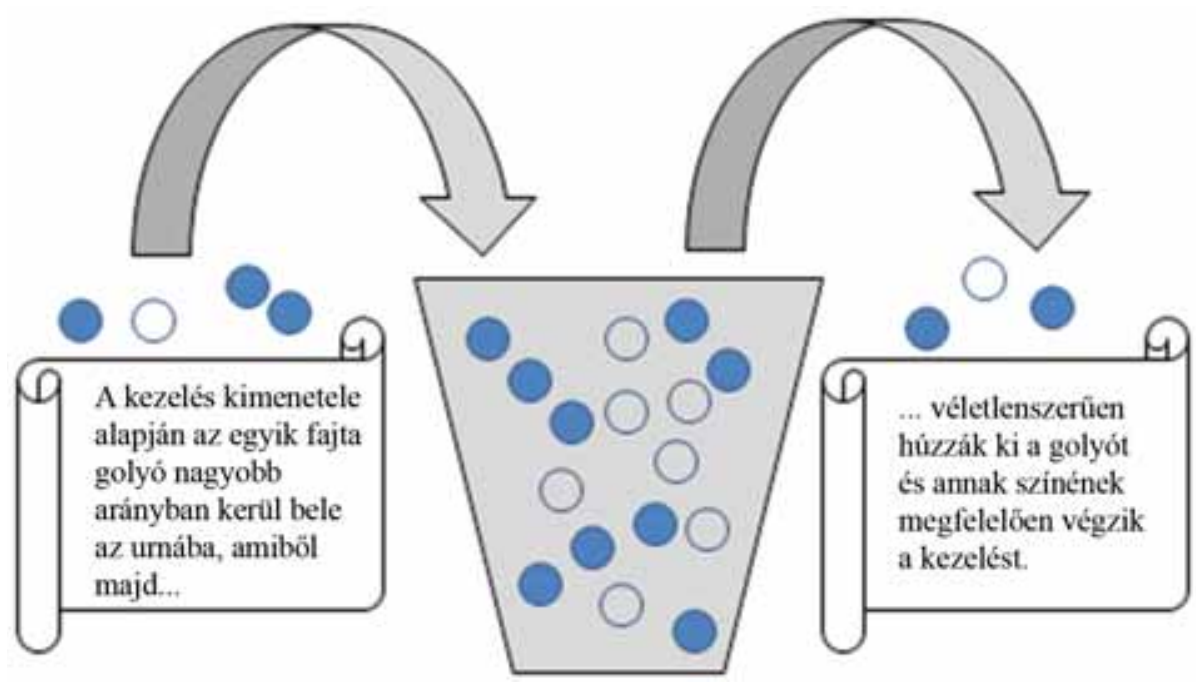

1. ábra

| Kimenetelfüggő randomizáció sematikus ábrája

nos a vizsgálati karokban, akkor igen nehéz a különféle karokban rögzített eredmények, különbségek értelmezése.

2. „Egymást követő csoportokra” épülő protokoll (group sequential design): a köztes statisztikai feldolgozás alapján lehetővé teszi az elemszám változtatását, de akár a vizsgálat korábbi lezárását biztonsági, hatásossági, hatástalansági okokból. Ilyen helyzet adódik, amikor:

- Nyilvánvalóvá válik a köztes analízisnél, hogy nem lehet majd a megcélzott betegszámmal érdemi különbséget kimutatni.

- Jóval ritkábban, de ennek ellenkezője is előfordulhat. A kisebb esetszám alapján is igazolható az elsődleges célpont. Ilyenkor sem etikus továbbvinni a vizsgálatot.

- A vizsgálat leállításának oka lehet természetesen a kétkarú vizsgálatban az egyik kezelési kar hátrányára igazolódó, aránytalanul sok mellékhatás is.

Ennek eldöntése jellemzően az úgynevezett független adatmonitorozó testület (independent data monitoring committee) jogköre. A köztes adatfeldolgozás történhet vak és nem vak módon is. A vak metodikával végzett analízis esetén a vizsgálat első fajú hibája nem romlik. (Első fajú hiba, amikor hatásosnak gondolunk egy eljárást, noha az a valóságban nem az. Ennek oka, hogy hibásan vetjük el a vizsgálati terv nullhipotézisét, miszerint például a placebo és a vizsgálati szer nem különbözik egymástól.) A nem vak feldolgozásnál a teljes vizsgálat első fajú hibája nem biztos, hogy alacsony szinten tartható, még kevésbé, ha egyéb adaptációk is módosítják az egész vizsgálatot, például, ha a bevont betegpopuláció jellemzője változik.

3. Az esetszám folyamatos, flexibilis újrabecslésére épülő protokoll (flexible sample size re-estimation design) alkalmazása a fentihez hasonló módon a vizsgálati populáció elemszámának lehetséges módosítását célozza meg, akár vak, akár nem vak metodikával. Az elemszám akár vak, akár nem vak metodikával történő változtatásánál sok szempontot kell figyelembe venni: az adatok variabilitását és annak változását, a kezelés hatásának nagyságát, a vizsgálat mások általi megismételhetőségének lehetőségét, a vizsgálat erejét. Talán a legnagyobb kihívás ebben az esetben az első fajú hiba növekedése. Minél többször, minél több szempont szerint vizsgálják az adatokat, annál nagyobb az esélye, hogy (véletlenül) statisztikailag releváns különbséget találnak az adatokban az egyes kezelési karok között. Felmerül a pragmatikus kérdés, lehetne-e a klinikai vizsgálatokat egy alacsony elemszámmal indítani, és azt a köztes adatfeldolgozások alapján szükség esetén lépésenként emelni? Tekintve, hogy ezek az elemszám-módosítások becslésen alapulnak és a becsléseknek jelentős variabilitása van, nem feltétlenül célravezető ez a stratégia.

4. Az „Ejtsd a veszteseket, játszd a győztest!” protokoll (Drop-the-losers, play-the-winner design) egy többlépcsős adaptív vizsgálati terv. Az egyes köztes analízis után például a hatástalan vagy túl sok mellékhatást mutató kezelési karokba a bevonást csökkentik, és egyre nagyobb arányban randomizálják a betegeket a többi karba. Előre definiált mérföldköveknél, korábban meghatározott kritériumok alapján a hatástalan adagokat vagy az aránytalanul sok mellékhatást okozó kezelési karokat kiveszik a vizsgálatból, és a további betegeket a megmaradt csoportokba, illetve újonnan megállapított dóziskarba sorolják. Ha van kontrollkar, akkor azt jellemzően megtartják. Különösen hasznos ez az elrendezés, ha a dózistartomány még bizonytalan, például fázis 2-ben. Nagyon fontos kérdés, hogy milyen kautélák mellett döntenek az egyes vizsgálati karok további sorsáról. Látni kell, hogy a kiesett vizsgálati karok is tartalmaznak fontos adatokat a dózis-hatás összefüggéséről. Kérdés, hogy ezeket miképpen lehet hasznosítani a végső elemzésben? 
A kimenetelfüggő, adaptív vizsgálati elrendezésben a betegek nagyobb hányada kerül az előnyösebbnek tekinthető csoportba, mint a fix randomizáció esetén. Amennyiben kétkarú vizsgálatról van szó, ez a számbeli különbség nem jelentős. Eközben a teljes betegszám viszont a kimenetelfüggő, adaptív vizsgálatban nagyobb. Ennek az eredője, hogy valamivel nagyobb számú beteg fog a kevésbé ígéretes kezelési karba sorolódni. Más szóval, gyakran előfordul, hogy egy kétkarú, kimenetelfüggő, adaptív vizsgálatban több betegre, hosszabb időre van szükség a vizsgálat alapvető kérdésének megválaszolásához, mint a klasszikus fix randomizációnál [9]. A kimenetelre épülő adaptív randomizáció több kezelési kar esetén nyújthat előnyöket, amikor a kimenet befolyásolja a további betegbevonást. Amikor több mint két kezelési kar van és több hipotézist is vizsgálnak (például nemcsak, hogy jobb-e, mint a placebo, hanem melyik dózis a legmegfelelőbb), akkor a különféle kezelési karok közül az előnytelenek korábbi leállítása és a további betegek átterelése az ígéretes karokba etikailag is elfogadható, mivel az összes betegteher ebben a vizsgálati szerkezetben kisebb lesz [10].

5. Az adaptív dóziskeresésre épülő protokoll (adaptive dose finding design) régről ismerős lehet az exploratív, fázis 1 -es és 2 -es vizsgálatokból. A fázis 1 -es vizsgálatban a maximális, tolerálható dózis meghatározásánál egy előre rögzített séma szerint emelik a készítmény adagját. Leegyszerűsítve ez a következő lehet: mindig 3 egészségesnek adják a következő dózist, ha nincs panasz, tovább emelik az adagot, viszont ha mellékhatás jelentkezik, akkor 3 új önkéntes ugyanazt a dózist kapja. Ha ismét jelentkezik az a mellékhatás, akkor nem mennek feljebb az adaggal. Természetesen a farmakokinetikai és farmakodinámiás adatok részei a maximális tolerálható adag meghatározásának.

Az adaptív dóziskeresésnél például fázis 2/3-as vizsgálatban a protokoll egy készítményspecifikus, dózis-toxicitás modellt használ és a klinikai adatokat folyamatosan Bayesian statisztikai módszerrel elemzik. A lépéseknél használt elemszám változhat, köztes dózis beléptetésére, dózisvisszalépésre is lehetőséget teremtenek a vizsgálati protokollban, ezáltal a legfontosabbnak bizonyuló szúkebb dózis-hatás tartományban gyưjtenek több információt. Amennyiben az adaptív dóziskereséssel előbb találjuk meg a megfelelő dózistartományt, akkor reményeink szerint kevesebb beteget teszünk ki felesleges mellékhatásoknak, illetve szuboptimális kezelésnek. A kisebb betegszámnak van egy másik következménye is. Azáltal, hogy előbb megtaláljuk a megfelelő adagolást, ez azt is jelenti, hogy kevesebb biztonsági adatot gyưjtöttünk. Ez leginkább a ritkábban jelentkező, súlyos mellékhatások megléte esetén probléma.

6. Biomarkerre épülő adaptív protokoll (biomarkeradaptive design): a vizsgálat módosításának mikéntjét farmakokinetikai, farmakodinámiás és/vagy genomikán alapuló markerekre építi. Ez a jelen és a közeljövő talán legizgalmasabb és legígéretesebb fejezete. Az innovatív készítmények fejlesztésekor a szóba jövő biomarkerek is még megismerésre várnak. A biomarkerek használatához a szükséges szúrési metodikát ki kell még fejleszteni, az eljárást validálni kell, azaz igazolásra vár, hogy a beazonosított biomarker jellemzője mennyire korrelál a klinikai kimenetellel. Megkülönböztetünk prognosztikai és prediktív markereket. A prognosztikai biomarker előrejelzése független a kezelés jellemzőitől. Ilyen például az életkor, betegség súlyossága, a meglévő szövődmények. Ezek a markerek arról tájékoztatnak, hogy kezelés nélkül milyen lefolyás lenne várható. A prediktív biomarkerek a kérdéses kezelésnek a vizsgált kimenetelre való hatását jelzik előre, például a célzott farmakodinámiás hatáshoz szükséges enzimaktivitás jelen van-e [11]. A biomarkerre épülő adaptív vizsgálat segíthet kiválasztani a megfelelő betegpopulációt - azokat a betegeket vonják be, akiknél a hatóanyag által megcélzott receptor, enzim, DNSszekvencia stb. jelen van -, és ezáltal ez a módszer a személyre szabott orvoslás felé tett újabb lépést jelenti. A biomarkerek használatához elengedhetetlen, hogy arra a markerre sztenderdizált szúrési metodikával rendelkezzenek, és legyen egy validált prediktív modell a biomarkerre.

A biomarkerre épülő adaptív technikák ismertetésénél szót kell ejtenünk a betegbevonásnál alkalmazott szưrési, kiválogatási módszerekről és azon belül is a „dúsításról” (enrichment). A protokoll bevonási és kizárási kritériumai szürők, hogy a csak a vizsgálat céljainak legjobban megfelelő betegek kerüljenek be a vizsgálatba. Ezen filterek közül több is magától értetődő, például legyen egyértelmúen klinikailag, laborral kimutatható a kérdéses betegség, előreláthatóan a beteg múködjön együtt a vizsgálati procedúrákkal. A vizsgálat érzékenységének érdekében a betegek heterogenitását, ezáltal a kimeneteli paraméterek variabilitását csökkentik, ami természetesen az eredmények érvényességét kérdőjelezheti meg a teljes, nem szűrt betegpopulációban. Ilyen bevonási, kizárási feltétel, hogy csak bizonyos súlyosságú és például más betegségben nem szenvedő alanyok kerülhetnek a vizsgálatba. A prognosztikai „dúsítási” technikák közé tartoznak azok, amelyekkel mondjuk egy, az állapotromlást akadályozó kezelés vizsgálatánál azokat a betegeket vonjuk be, akiknél a várható kedvezőtlen eseményt nagyobb valószínűséggel találjuk meg (például migrénes rohamot). Ezáltal a placebokar és az aktív kezelésben regisztrált állapotromlás között kevesebb bevont beteggel kell dolgozni.

Prediktív dúsítási technikák azok, amelyek segítenek beazonosítani és bevonni (csak) azokat a vizsgálati alanyokat, akik leginkább fognak reagálni a vizsgált kezelésre, készítményre: például kimutatható a betegnél a kérdéses receptor, gén, enzimvariáns, ami a készítmény farmakodinámiás hatásához szükséges. A vizsgálat kezdetén adhatnak szimpla vak módon tesztdózist, a kérdéses hatóanyagból, és csak az arra reagálókat engedik a vizsgálat következő fázisába, hogy a későbbi reszponderek aránya javuljon. Máskor szimpla vak placebokezelés- 
sel indítanak, és a placeboreszpondereket nem vonják be a kettôs vak randomizált vizsgálati fázisba.

A „dúsítási” technikák nagy kérdése, hogy mennyire általánosíthatók a vizsgálati betegcsoport adatai, hiszen túl a klasszikus bevonási-kizárási kritériumok szűrőjén, gyakran a placebóra reagálókat, a tesztdózisra nem reagálókat is kizárják, hogy növeljék a vizsgálatnak az érzékenységét (assay sensitivity). (Az assay sensitivity fogalma azt takarja, hogy a vizsgálati protokoll és az egész vizsgálat menete alkalmas kimutatni azt a különbséget, amit vizsgálunk.) A vizsgálat erejének (power) növelése a különféle dúsítási metodikák által - azaz sikeresen kimutatni a kezelés hatását, ha az valóban fennáll - elfogadott és széles körben alkalmazott technika [12].

7. Adaptív terápiaváltásra épülő protokoll (adaptive treatment-switching design) alkalmazásánál a vizsgálónak lehetősége van a kérdéses betegnél a vizsgálat elején beállított kezelés változtatására, amennyiben annak oka a várt hatás elmaradása vagy mellékhatások megjelenése. Leginkább onkológiai vizsgálatban élnek ezzel a lehetőséggel, amikor a progresszió a kezelés ellenére is nyilvánvalóvá válik. Ezek a változtatások magukkal vonják az egész vizsgálat elemszámának is a változtatását, hogy a vizsgálat ereje ne gyengüljön.

A vizsgálat ereje adja meg, hogy hány százalékos esélylyel rendelkezik a vizsgálat, hogy ki tudja mutatni például a kétféle kezelés között a különbséget, ha az valóban fennáll.

8. A vizsgálati hipotézis adaptív változására épülő protokollról (adaptive-hypotheses design) akkor beszélünk, ha a vizsgálati terv megengedi a menet közbeni analízis eredménye alapján, a vakság feloldása előtt a vizsgálati hipotézis változtatását. Ilyen lehet a „jobb, mint a másik” (superiority) vizsgálati hipotézis felváltása a „nem rosszabb, mint a másik” (non-inferiority) hipotézissel. Természetesen fontos a szükséges elemszám újraellenőrzése, és annak a klinikai és statisztikai különbségnek az indoklása, amit még elfogadnak, mint „nem rosszabb, mint a másik”. A hipotézis adaptív változtatására másik példa - ugyancsak vak analízis alapján - a másodlagos és elsődleges végpontok cseréje vagy az azokból kialakított összetett végpont (composite endpoint) használata.

9. „Döccenésmentes” protokoll (adaptive seamless design): az egyik leggyakrabban alkalmazott metodika a gyógyszerfejlesztésben annak költséghatékonysági elönyei okán.

A jól ismert klasszikus eljárás, amelyben az exploratív fázis 2 lezártával megállapítják az optimálisnak tekinthető dózistartományt, majd fázis 3-ban, nagy betegszámon igazolják, cáfolják a kezelés kockázat-haszon arányát. Ez két külön vizsgálat, köztük az adatok értelmezéséhez szükséges szünettel.

A „döccenésmentes” (seamless) fázis $2 / 3$ vizsgálat egy tanulási és egy konfirmatív fázisra osztható. A kettő között megszakítás nélküli átmenet van. A végső analízisben az adaptív változások előtti és utáni betegadatokat egyaránt feldolgozzák. Ez az eljárás, a remények szerint, rövidíti a humán fejlesztés idejét. Ugyanezt a „döccenésmentes" eljárást lehet használni fázis 1 és 2 áthidalására is, például onkológiai vizsgálatokban. Csak betegeket vonnak be, és az első fázisban a mellékhatásokra fókuszálva keresik a megcélozható dózistartományt - magától értetődően farmakokinetikai markerek támogatásával -, majd a második fázisban a korai hatásossági és farmakodinámiás biomarkeradatokat is begyüjtik.

Több fontos kérdés is adódik az 'adaptive seamless design' kimenetelének értelmezésekor. Miképpen végezzék el az adatok analízisét, ha az első és a második fázisnak a célja és végpontja nem ugyanaz? Valid-e ez a metodika és valóban hatékonyabb-e, mint a klasszikus kétlépcsős stratégia?

10. A több adaptív technikát egyszerre használó protokoll (multiple adaptive design) attraktív lehetőség elsősorban annak flexibilitása okán, de nagyon bonyolult vizsgálatot és problémás, komplex analízist jelent. Nagy a veszélye ugyanis a szisztematikus hibáknak. A vizsgálat menete alatt módosulhat egyszerre a bevont betegcsoport, a randomizáció menete, a megcélzott kimenetel és annak paramétere, a vizsgálók hozzáállása a szakmai problémához, de változik az alkalmazható statisztikai eszköztár is.

Amennyiben a változtatás kizárólag nem a kérdéses vizsgálat adatain alapszik, akkor azt nem tekintik adaptive designba tartozónak. Hasonlóképpen a vizsgálati trendek folyamatos követését sem tekintik adaptive designhoz tartozónak, amennyiben az vakon történik [4].

Az adaptí vizsgálati protokollok felvértezhetik a vizsgálatot további lehetöségekkel is:

- A tervezett betegvizitek számát lehet süríteni biztonsági okokból, de lehet ritkábbá tenni, ha az állapot lassú változása azt lehetővé teszi.

- A betegbevonás és -benntartás támogatása érdekében a kiegészítő kezelések, együtt adható szerek esetleges módosítását is belefoglalhatják. Ez persze növeli a kimenetel varianciáját, de az esetszám megtartása fontosabb lehet, ha egyes szükséges kiegészítő kezelések gyakran fordulnak elö.

- Diagnosztikai és laborprocedúrák módosításának keretét ugyancsak elöre meg lehet adni, hogy a begyújtött klinikai és egyéb adatok a közben beérkező, külső információk tükrében értelmezhetőek legyenek. A vizsgálatok menetének változtatása előfordulhat, ha például a kiegészítő tesztek kifejezetten drágák, de a klinikai vizsgálat első része arra mutat rá, hogy azokra feltétlen szükség lesz a teljes vizsgálati adatbázis analízise során.

- Az alkalmazott vizsgálati készítmény adagja, frekvenciája, a kezelés hossza, a beavatkozás tartama, módja is opcionálisan változtatható az összes betegnél. Lényegében ezt takarja az adaptív dóziskeresés és a seamless vizsgálati protokoll is.

- Nemcsak a klinikai aspektusok, hanem a statisztikai analízis is tárgya lehet az adaptív vizsgálati protokollnak. Előre meg kell határozni, hogy a vizsgálat során 
mikor és milyen premisszák esetén változtatják az interim feldolgozási időpontját, számát, a vizsgálati végpontokat, illetve a statisztikai analízis módszereit.

A beteg-beleegyezés folyamata ma is gyakran 15-25 oldalas anyag elolvasását és megértését feltételezi. Az adaptív vizsgálat bemutatása ezen nemhogy nem javít, de feltehetően megnehezíti annak befogadását, átlátását, hogy mi is fog történni a vizsgálat alatt. Érdekes módon egy friss vizsgálat mégis azt mutatta ki, hogy a betegek például egy hipotetikus, kimeneteltől függő randomizációs, stroke-vizsgálatban szívesebben vettek volna részt, mint a klasszikus fix randomizációval múködő szokásos vizsgálatban. Az első esetben a betegek 67,3\%-a, a másodikban a betegek 54,5\%-a egyezett (volna) bele, hogy bevonják a kérdéses vizsgálatba [13].

Nem szabad elfelejteni, hogy nem egy vizsgálattal ismerjük meg a vizsgálati készítményt, hanem azt egy fejlesztési folyamaton visszük végig, és az egyes fázisokban más-más kérdések megválaszolására összpontosítunk. Egy exploratív fázis 1 és 2 , illetve a 'proof of concept study' hipotéziseket generál, és csak a leggyakoribb, gyorsan jelentkező biztonságossági problémákra világít rá. A konfirmatív fázis 3-as, 4-es vizsgálatok tudnak végső választ adni a hatóság és a mindennapok gyakorlati kérdéseire, mind a dozírozás, mind a megcélzandó betegalcsoportok és mellékhatás tekintetében. Az adaptív vizsgálati technikák egyes módszerei $(3 ., 6 ., 7 ., 10$.$) in-$ kább az exploratív szakaszban, mások $(4 ., 5 ., 8$.) a konfirmatív humán fejlesztési szakaszban lehetnek hasznosak, hatékonyak.

\section{Következtetések}

A gyógyszerfejlesztés versenyében az előforduló döntési helyzetekre gyorsan és korán kell és lehet is ma már reagálni. A fơ cél, hogy az új készítményekkel, eljárásokkal a lehetséges egészségnyereséget mihamarabb elérhetővé tegyék. Egy másik cél, hogy a milliárd dollárban mérhető gyógyszerfejlesztési projektek nagyobb arányban és hamarabb hozzák meg a befektetőknek a hasznot. Az elmúlt évtizedek humán, klinikai vizsgálati tapasztalatai, a számítástechnika, a biostatisztika fejlődése lehetővé tette az adaptív vizsgálati metodikák kialakulását és fejlődését. A vizsgálat menetének egy előzetesen lefeketett kereteken belüli változtatása, például az elemszám újrabecslése, lehetővé teszi, hogy az addig befektett energia, idő és pénz ne vesszen el, ha mondjuk a várható terápiás különbség kisebb, mint korábban azt feltételezték, de a nagyobb elemszámmal kimutatható lenne. A vizsgálat mihamarabbi leállítása akkor is fontos, ha a köztes analízis alaján a klinikai projekttől nem várható hasznosítható eredmény. Ugyancsak a betegek érdekét támogatja az adaptív vizsgálati protokoll, amikor azokat a vizsgálati karokat nem viszik tovább, amelyekről már a vizsgálat alatt világossá válik, hogy a betegeknek nem várható belőlük terápiás haszna vagy aránytalan rizikónak vannak kitéve. Orvosetikai kötelesség, hogy ahol a terápiás esélyegyenlőség nem áll fenn, azokat a kezelési karokat mihamarabb leállítsák. (A terápiás esélyegyenlőség azt mondja ki, hogy akkor etikus egy klinikai vizsgálat, ha a rendelkezésre álló adatok alapján valóban nem tudjuk, hogy a különféle vizsgálati karok között, illetve a klinikai vizsgálatban való részvétel és az elérhető, sztenderd kezelés között van-e érdemi különbség.)

Láttuk, hogy a vizsgálati paraméterek, de a vizsgálati cél, a hipotézis változtatásának lehetőségét is be lehet építeni egy adaptív protokollba. Ezek inkább a korai, exploratív fázis 2-es vizsgálatoknál alkalmazható lehetőségek. Természetesen ez a flexibilitás komoly kihívásokat jelent a vizsgálat megvalósításánál és a végső értékelésnél. Kérdés, hogy a változtatások során sikerül-e kikerülni a szisztematikus hibák lehetőségét, megtaláljuk-e az analízis után a gyógyszerfejlesztés továbbviteléhez szükséges kérdésekre a válaszokat? Minél több változtatást léptetnek életbe egy vizsgálaton belül, annál nehezebb lesz a végső eredmény értelmezése, tehát akár kontraproduktív is lehet az adaptív metodikák használata.

$\mathrm{Az}$ adaptív vizsgálat megtervezése több időt vesz igénybe az elején, jóval intenzívebb csapatmunkára, kommunikációra, gyors döntéshozatalra van szükség a vizsgálat során. Mindezt a flexibilis, risk-based (a problémákat megelőző, azokra költséghatékonyan reagáló) monitorozás kell, hogy támogassa.

Mit nyújthat az adaptí vizsgálati tervezés?

- Hatékonyabban gyújti össze a szükséges klinikai adatokat.

- Növeli a vizsgálat sikerének lehetőségét.

- A kezelés hatásának jobb megértését adja, például a dózis/hatás görbe arra a sávra koncentrál, ami releváns.

- Az alultervezett és a túlbiztosított klinikai vizsgálatokat kiiktathatja.

- A rendelkezésre álló idő, tőke, munkaerőforrás és betegpopuláció jobb allokációját teszi lehetővé [4].

Melyek az adaptív vizsgálatok kockázatai?

- Megnóhet az esély, hogy álpozitív következtetésre jutunk.

- A pozitív eredmény meggyőző interpretációja nehézségekbe ütközhet. Ezek leginkább a vak értékeléssel kezelhető veszélyek.

- A „döccenésmentes” 2/3-os vizsgálatban az átmenetben az elemzésre hagyott rövid idő kapkodást, nem megalapozott döntést okozhat. Az alapos adatelemzés jelentősége óriási [4].

Melyek azok a változtatások a vizsgálatban, amelyek nem tartoznak az adaptív vizsgálattervezés kategóriájába?

- Protokollmódosítás azt követően, hogy előre nem látható eredményt találtak a köztes feldolgozás során.

- A vizsgálat menetének megváltoztatása, amit kizárólag olyan információ alapján léptetnek életbe, ami nem a kérdéses vizsgálatból származik. (Például más vizs- 
gálatból származó releváns biztonsági adatok megváltoztatják a kockázat/haszon arányt; új ismeretek kerülnek elő a betegség patofiziológiáját illetően.) Ezeket reaktív revíziónak nevezik. Alapvető, hogy annak, aki ezt a változtatást életbe lépteti, ne legyen rálátása a nem vak eredményekre [4].

Az ipar által kezdeményezett projektekben az adaptív vizsgálati lehetőség egy-egy elemét minden ötödik klinikai vizsgálatban megtalálni. Ez lehet a köztes adatfeldolgozás kapcsán történő vizsgálatleállítás, lehet az elemszám módosítása. Minden bizonnyal egyre több ilyen eszközt fognak használni nemcsak a konfirmatív (3-4 fázis), hanem az exploratív vizsgálati szakaszban (1-2 fázis) is. Nagy kihívás a projekt operatív menedzselése, egy adaptív vizsgálatban a különféle részlegek közti intenzív kommunikáció hatékony megszervezése, irányítása. Ezeknek az innovatív eszközöknek a lassú elterjedésében sokszor a gyógyszercégen belüli idegenkedés a fó akadálya. A hatóságok részéről megvan a fogadókészség, és felkészültebbnek tünnek ebből a szempontból [14].

A tradicionális humán gyógyszerfejlesztésnél, a vizsgálatok tervezésénél a rendelkezésre álló adatok birtokában felvázolnak egy elképzelést a várható hatás- és mellékhatásprofilról, annak változékonyságáról, az akkor meglévő dózis-hatás összefüggés preklinikai és klinikai adatai alapján. Megbecsülik a bevonási, kiesési rátákat, a betegek várható együttmúködését stb. és elindítják a klinikai projektet. Ha mindezek az elképzelések - amik akkor és ott a legjobbak voltak - nem igazolódnak, vagy újabb adatok az eredeti vizsgálati protokoll sikerét megkérdőjelezik, akkor protokollmódosítást írnak, hagyatnak jóvá. Ez a fajta vizsgálatvezetés időveszteséggel jár és sokba is kerül. Egy Tufts Center for the study of Drug Development felmérés alapján egy protokollmódosítás átlagosan körülbelül félmillió dollár költséget jelent a szponzor számára [14].

Anyagi támogatás: A közlemény megírása anyagi támogatásban nem részesült.

A szerző a cikk végleges változatát elolvasta és jóváhagyta.

Érdekeltségek: A. J. a PAREXEL Magyarország Kft., a klinikai vizsgálatokat a gyógyszergyárak számára végző nemzetközi cég szakembere és magyar cégvezetője.

\section{Irodalom}

[1] Scott, B. M.: The design of complex adaptive trials. October 22, 2012. https://www.youtube.com/watch? $\mathrm{v}=\mathrm{yGByViFfRNE}$

[2] Sfera, D.: Running adaptive clinical trials myth and reality. https://www.youtube.com/watch?v=w2R_vBvaLwo

[3] European Medicines Agency: Reflection paper on methodological issues in confirmatory clinical trials planned with an adaptive design (CHMP/EWP/2459/02). London, 2007. http://www. ema.europa.eu/docs/en_GB/document_library/Scientific_ guideline $/ 2009 / 09 /$ WC500003616.pdf

[4] U.S. Food and Drug Administration: Guidance for industry adaptive design clinical trials for drugs and biologics (draft guidance). Rockville, 2010

[5] Gallo, P., Chuang-Stein, C., Dragalin, V., et al.: Adaptive designs in clinical drug development - an executive summary of the PhRMA working group. J. Biopharm. Stat., 2006, 16(3), 275283.

[6] Elsüßer, A., Regnstrom, J., Vetter, T., et al.: Adaptive clinical trial designs for European marketing authorization: a survey of scientific advice letters from the European Medicines Agency. Trials, $2014,15,383$

[7] Chow, S. C., Chang, M.: Adaptive design methods in clinical trials - a review. Orphanet J. Rare Dis., 2008, 3, 11.

[8] Chow, S. C.: Adaptive design methods in clinical research. www. omicsonline.org/editor-ppt/SheinChung_Chow.ppt, OMICS Publishing Group, 2014.

[9] Begg, C. B.: Ethical concerns about adaptive randomization. Clin. Trials, 2015, 12(2), 101

[10] Hey, S. P., Kimmelman, J.: Are outcome-adaptive allocation trials ethical? Clin. Trials, 2015, 12(2), 102-106.

[11] Wang, S. J., Hung, H. M.: Adaptive enrichment with subpopulation selection at interim: Methodologies, applications and design considerations. Contemp. Clin. Trials, 2013, 36(2), 673-681.

[12] U.S. Department of Health and Human Services, Food and Drug Administration, Center for Drug Evaluation and Research (CDER), Center for Biologics Evaluation and Research (CBER), Center for Devices and Radiological Health (CDRH): Enrichment strategies for clinical trials to support approval of human drugs and biological products. Draft guidance. Clinical Medical, December 2012. http://www.fda.gov/downloads/Drugs/ GuidanceComplianceRegulatory/Information/Guidances/ UCM332181.pdf

[13] Tehranisa, J. S., Meurer, W. J.: Can response-adaptive randomization increase participation in acute stroke trials? Stroke, 2014, 45(7), 2131-2133.

[14] Tufts Center for the Study of Drug Development: Tufts CSDD impact report: The adoption and impact of adaptive trial designs. 2013. http://www.iconplc.com/icon-files/docs/thought-leadership/ premium/TuftsCSDD_Adaptive-Design-Trials-Sr-Mgmt-Brief_ May2013.pdf
(Antal János dr., Budapest, Hermina út 17., 1146 e-mail: janos.antal@PAREXEL.com) 